\section{Repensando la política desde el diseño (y el diseño desde la política)}

RETHINKING POLITICS FROM DESIGN (AND DESIGN FROM POLITICS)

36 INTRODUCCIÓN_INTRODUCTION
Eatior invitado_Guest

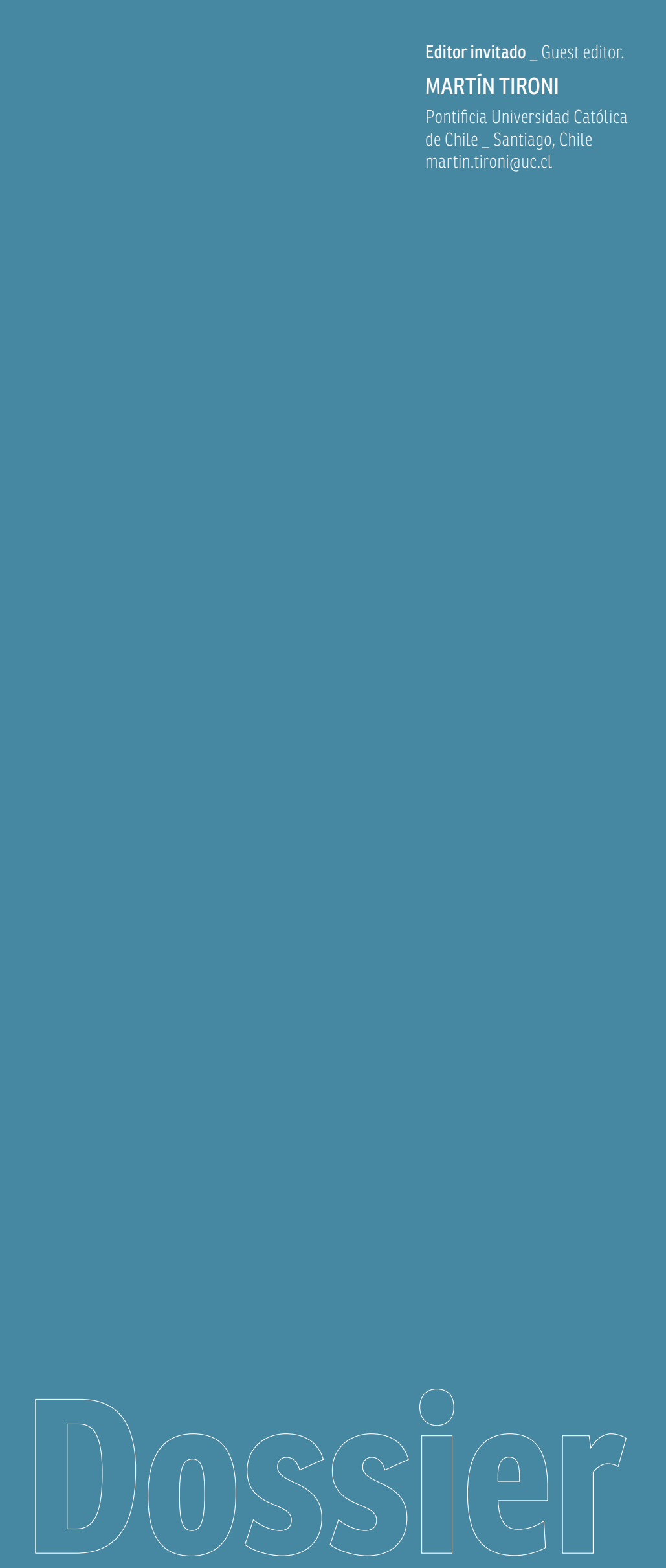

¿Qué tiene que ver el diseño con la política? La respuesta habitual sería: nada. A primera vista, la politica sería un dominio indiferente y ajeno al del diseño. Mientras la politica debe ocuparse del gobierno de los intereses humanos en función del bien común, el diseño, en cambio, se enfocaría en la forma, en la disposición estética y funcional de las cosas que pueblan el mundo. El territorio de lo político estaría poblado por normatividades y valores (libertad, igualdad, tolerancia, etc.), fundando su quehacer en lo que Weber llamó "el uso legítimo de la fuerza" (Weber, 1944). El campo del diseño, por su parte, respondería al imperio de la necesidad del usuario, abocando sus fuerzas a transformar, creativa y sensiblemente, las materialidades en productos útiles, usables o decorativos.

Conforme con esta concepción, el diseño sería simplemente un medio sobre el cual actúan las fuerzas de la políticay la cultura. Es cierto que a través de los objetos de diseño podríamos reconocer categorís sociases aceder a una seriede signifacs (B) Sobre bje Perobis vistillza Vis Descelo politico. Desde sta on

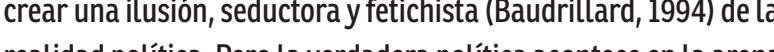

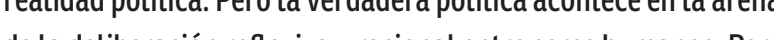
dela diberacion papt, argumentios a propiedades polictas no solamene parecen equivocado. sería Es precisamente el divorcio entre la política y el diseño, sumamente arraigado en el pensamiento y acción de este úttimo, lo que este dossier busca tematizar y problematizar. Con tal propósito, esta edición de Diseña indaga más allă de los límites restrictivos que le fueron tradicionalmente otorgados al diseño, instalando interrogantes respecto de un diseño que reflexiona empíricamente sobre las condiciones para la perdurabilidad y habitabilidad del mundo (Sloterdijk, 2014). En lugar de entender el diseño y la política como dominios contrapuestos y ontológicamente estables, creemos relevante revitalizar el impulso político del diseño, esto es, su capacidad para co-producir lo social y desplegar nuevos asuntos políticos. Las prácticas de diseño constituyen un espacio particularmente fructiffero para reflexionar sobre la multiplicidad de entidades, fructifero para reflexionar sobre la multiplicidad de entico (Stengers, 2005). Ellas permiten indagar en las condiciones socio-

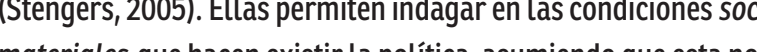
materiales que hacen existir la politica, asumlendo que esta no es unap

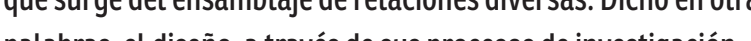
palabras, el diseño, a través de sus procesos de investigacion
y fabricación, puede tematizar asuntos politicos que son
What has design to do with politics? The usual answer would and alien to design. While politics must deal with the governing of human interests for the sake of common good, design, instead, would be focused on form, the aesthetic and functional arrangement of the things that populate the world. The realm of the political would be populated by norms and values (liberty, tolerance, etc.), founding its duties on what Weber called 'the legitimate use of force' (Weber, 1944). The field of design, on its part, would respond to the rule of the needs of the user, focusing its forces on transforming, creatively and sensitively, the materialities into useful, usable or decorative products.

According to this conception, design would be merely a medium over which the forces of politics and culture act. It is true that access a series of meanings about the status of a given socia gro (Bourdieu, 1979). But under this premise design acts as a mediator that makes certain positions visible in the social structure, but that by itself wouldn't offer a strictly politicat mode of existence, nor would it be worthy of it It moldt at most be an accessory of the polvi contribute to create the ellusion seductive and fetishist Baudrillard, 1994) of the politicat reatity But the reat politiss tates pace in the (an So, to argue that he forna of So, to argue that he firms of dasign possess in henselves poltical properties would not only seem mistasen.t would mean for desiig medang ha nela wherell has no competere.

It is precisely the separation between politics and design, deeply rooted in the thought and action of the latter, which this dossier attempts to thematise and problematise

With this in mind, this edition of Diseña explores beyond the restrictive boundaries that were originally imposed on design, installing questions about a design that reflects empirically on the conditions for the sustainability and habitability of the world (Sloterdijk, 2014). Instead of understanding design and politics as opposing and ontologically stable domains, we believe it's relevant to revitalize design's political drive, that is, its capacity to coproduce the social and unfold new political issues.

The practices of design are a particularly fruitful space to reflect on the multiplicity of entities, agencies and interweavings that constitute the political sphere (Stengers, 2005). They allow to explore the sociomaterial conditions that make politics exist, assuming that this is not exclusively a prerogative of the human domain, but that it emerges from the assembling of diverse relations. In other words, design, through its processes of research
resting and fabrication, an thematise politica issues that are of researc of in other records, expanding the ways of enacting the political 
impensados a través de otros registros, ampliando las formas de enactar lo político (Mol, 2005). Esto supone concebir el diseño no solo como una herramienta o equipamiento externo de lo político, sino como constituente de cualidades particulares de lo politico. El rol político del diseño, consecuentemente, va más allá de la ideología que portan los artefactos, y se relaciona con el modo en quelos objest fomasy mateilidades deliserocopodreny que los objetos, formasy
re-programan lo social.

La reflexión sobre las dimensiones políticas y morales de diseño no es un asunto nuevo. Autores como Papanek (1970) y Flusser (2022), entre otros, se han interrogado sobre la ineludible responsabilitad moral del diseño en la expansión de la sociedad de consumo. Sin embargo, durante los ultimos años las preguntas respecto de las configuraciones políticas que ofrece el diseño no han cesado decomplejzarsey de incorporar nuevas resonan (Stiegler, 2006; Latour, 2008; Sloterdijk, 2014). En la medida que los efectos del diseño se aplican a ciudades, genes, paisajes, políticas, animales, algoritmos, colectivos, chips y servicios, es urgente reflexionar sobre su rol ético en la construcción de subjetividades y en la configuración de nuestras formas de existencia. Por otra parte, el imperativo adosado a la actividad de diseño contemporáneo de tener que responder a las necesidades de la sociedad de consumo ha llevado a importantes reflexiones sobre cómo el diseño puede moldear cuerpos, subjetividades y espacios (Foucault, 1990, Schull, 2012; Woodhouse \& Patton, 2004), entre las cuales se cuentan la de Albena Yanevay la de Tomás Sánchez Criado en este dossier.

Ignorar esta reflexión sobre el tipo de configuraciones que forja el diseño en nuestra vida sería ratificar una concepción decorativista del diseño, reduciendo su rol a una técnica de manufactura de productos y formas industrializadas. Liberar al diseño de su condición de saber subsidiario de otros campos (la política, la economía, la ingeniería, etc.) no solo es una invitación a la creación de saberes y prácticas transdisciplinares (Gunn, 0tto, \& Smith, 2013; Smith, et al., 2016) sino también una invitación a re-pensar el tipo de relaciones futuras que queremos establecer con nuestromediombiente.

Las formas y los artefactos creados por el diseño no están destinados solamente a ambientar o deleitar a los públicos sino también a producir y configurar lo social, haciendo gala de Dación ontológica que requiere ser analizada críticamente (Sloterdijk, 2014; Stiegler, 2006). Al reconocer estas habilidades del diseño para producir eventos socio-polítices, se abre una via para examinar cuáles son las distincionesy Deras Disenar es una forma singular de conocery ordenar el mundo, de materializary fabricar idearios, de generar futuros significadosy practicas. Por lo mismo, su actividad ejerce un rol performativo humanos, materialidades y medioambiente (Anusas \& Ingold, 2013; Latour, 2010).
(Mol, 2005). This supposes conceiving design not as a tool or equipment outside the political but as a constituent of specific qualities of the political. The political role of design, consequenty goes beyond the ideolology that artefacts carry, and which is related to the way in which objects, forms and materialities of desion coproduce and re-program the social.

The reflection on the political and moral dimensions of design is not something new. Authors like Papanek (1970) and Flusser (2002), among others, have wondered on the unavoidable moral responsibitity of design in the expansion of the consumer society. However, during recent years the questions regarding the politica configurations that design offers have become increasingly complex, incorporating new resonances (Stiegler, 2006; Latour, 2008; Sloterdijk, 2014). As the effects of design apply to cities, genes, andscapes, policies, animatis, algorithms, collectives, chips and services, it is urgent to reflect on its ethical role in the construction of subjectivities and in the configuration of our forn of existence. On the other hand, the imperative attached to the activity of contemporary design of having to respond to the needs of consumer society has ted to important reflections on how design can mould bodies, subjectivities and spaces (Foucault, 1990; Schüh, 2012; Woodhouse \& Patton, 2004, among them, those by Albena Yaneva and by Tomás Sánchez Criado in this dossier.

To ignore this reflection on the types of configuration that design forges in our lives would be to reaffirm a decorativist conception of design, reducing its role to a manufacturing technique for products and industrialised forms. Liberating design from its condition of being a discipline subsidiary to other fields (politics, economy, engineering, etc.) is not only an invitation to the creation of transdisciplinary knowledge and practices (Gunn, Otto, \& Smith, 2013; Smith, et al., 2016), but also an invitation to re-think the types of future relations that we wish to establish with our environment. The forms and artefacts created by design are not destined solely to decorde to thease the publiss, but atso to prodice

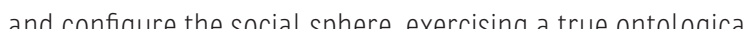
vocation that requires to be andysed critically (SLoterdijk 2014; Stiegler, 2006)

Recognising these abilities of design to produce socio-political events opens a way to examine which are the distinctions and singular forces that this form of knowledge introduces. Designing is a singular way of knowing and organising the world, of materiatising and fabricating ideologies, of generating future meanings and practices. For the same reason, its activity plays an indisputable performative role on the type of relations that are (Anusas \& Ingold, 2013; Latour, 2010.
A continuación queremos mencionar dos aspectos que relevan la condición política del diseño y que subja artículos aquí reunidos.

\section{AMPLIAR LA NOCIÓN DE POLITICA}

La reflexión sobre la acción política a partir del diseño debe stuarse en un debate mas amplio respecto de las on más-que-humanas que conforman la política. Este debate, recogido en varios de los artículos de este dossier, específicamente en la de Lenskjold y Jönsson; la de Dominguez Rubio y Fogué:y la de Farías y Correa, ha sido impulsado especialmente desde el campo de los Estudios de Ciencia y Tecnología (STS) y las recientes perspectivas provenientes del Design Anthropology (Gunn, Otto, 8 Smith, 2013; Smith, et al., 2016).

Surge la necesidad de ampliar la noción restrictiva de política, buscando reconocer otras agencias que participan en los procesos políticos. Se trata de una concepción más-quehumana de la política, donde en vez de confinar esta noción a una enunciación sustancialista, se analiza cómo otras entidad (animales, ríos, tecnologías, rocas, vegetales, etc.) pueden estar investidas de ciertas cualidades para resistir, diagramar y producir eventos políticos. Este programa flosófico, impulsado por autores como Stengers (2005; 2010), Latour y Weibe (2005) y Bennett (2010), propone rastrear escenarios para representar formas de coexistencias que incluyan entidades 列

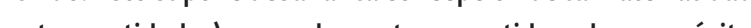
Jotras entid por com humanosy, por el contranio, tomarse en selo autonomíay las

Stengers (2005) y Latour (2007) han abogado por abrir la noción tradicional de polfitica hacia una cosmopolitica. Esta noción obliga a repensar la acción politica desde un "pluralismo ontológico", y abrirse a nuevas for mas de relación humanidadmedioambiente. Bajo este enfoque, el papel ético que puede cumplir el diseño en la composición y percepción de estos ensamblajes heterogéneos es fundamental (Binder, Brandt, Ehn, \& Halse, 2015; Yaneva \& Zaera-Polo, 2015). Como señalan Anusas e Ingold (2013), la práctica del diseño puede constitulf un espacio para hacernos conscientes y responsables de las interdependencias que nos constituyen. En oposición a la idea de diseño opaco, que tiende a oscurecer los ensamblajes que lo conforman, dichos autores sugieren formas de diseño que hagan perceptibles las circulaciones energéticas y las relaciones materiales que producen la vida.

La cosmopolítica, de esta manera, es una interrogación respecto de cómo queremos componer nuestro mundo (Latour, 2010). Con tal propósito, levanta interrogantes sobre las materialidades y agencias que podrín Legar a componer
Next, we'd like to mention two aspects that reveal the political condition of design, and which underlie the articles gathered here

\section{EXPADING THE NOTION OF POLTTCS}

The reflection on design-based political action must be situated In a wider debate with regard to the other more-than-human entities that constitute politics. This debate, picked up in several of the articles in this dossier, specifically in the ones by Lenskjold and Jonsson; by Dominguez Rubio and Fogué; and by Farias and Correa, has been driven especially from within the field of Science and Technology Studies (STS) and the different perspectives coming from Design Anthropology (Gunn, Otto, \& Smith, 2013; Smith, et al., 2016). The need emerges of expanding the restrictive notion of politics, seeking to recognise other agencies that participate in the political processes. It has to do with a more-than-human conception of politics, where instead of entrusting this notion to a rivers, technologies recks, vegetables, atc) may be invested of certain qualities to resist, lay out and produce political events This philosophical program, driven by authors like Stengers (2005) 2010) Latour and Weibel (2005) and Bennett (2010) proposes tracking scenarios to represent forms of coexistences that maj include heterogeneous entities and, thus, re-think the Political as a hybrid assemblage This supposes challenging the concention of materiality (and ther entities) as elements subiect to huma purposes and on the contrary take seriously the autonomy and other recaldir cest that may present entities (Harman, 2015)

Stengers (2005) and Latour (2007) have advocated for the opening of the traditional notion of politics towards a notion of cosmopolitics. This notion forces to rethink political action from environgen puatsm, and open to new forms of humanitythat design may have in the composition and perception of thes heterogeneous assemblages is fundamental (Binder, Brandt, Ehn, \& Halse, 2015; Yaneva \& Zaera-Polo, 2015). As pointed out by Anusas and Ingold (2013), the practice of design may constitute a space to make us aware and responsible of the interdependencies that consititute us. As opposed to the notion of opaque design, which tends to obscure the assemblages that conform it, the cited authors suggest design forms that make perceptible the energetic circulations and the material relations that produce life.

In this manner, cosmopolitics is an interrogation on how we wis to compose our world (Latour, 2010). With this purpose, it raises questions about materialities and agencies that may get to conform 
política, entendiendo este término no como la posibilidad de un mundo unificado o de un consenso generalizado, sino, por el contrario, como un mundo abierto a una polifonía de narracion y voces. Este proceso, más que requerir soluciones cerradas, invita a probar y prototipar, progresiva y delicadamente, eventos que permitan experimentar la cosmopolítica

Como señala Isabelle Stengers, la propuesta cosmopolítica contiene la pregunta respecto de cómo diseñar una escena pollica que nos proteja del egormo antropocentrico segunner intés hom

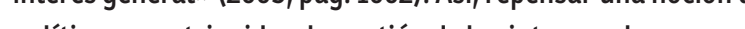

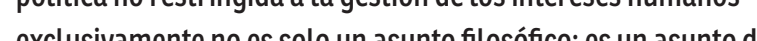
diseño (a matter of design).

Leño la matter of

La cosmopolítica como matter of design es una invitacion a reconocer los límites y alcances de los métodos del diseño centrados en los humanos, y a explorar formas de descentramiento a través de operaciones de co-diseño que permitan la inclusión de otras entidades invisibilizadas (Binder et al., 2015; Tironiy Hermansen, 2017). La potencialidad del diseño para investigar las condiciones para la cosmopolítica es igualmente una manera de tomar en serio el rol del diseño en mantención de los ambientes para la vida (Ingold, 2014).

¿Qué repertorios metodológicos son necesarios para hacerse perneable a las Simensiones "más que humanas", rastreando los ogias multiples que caracterizan nuestra vida? ¿Qué tipos de saberes encarnados y materializados posibilita los procesos de diseño que desafian las formas de producción de conocimiento de las ciencias sociales para pensar la cosmopolíticay la cohabitación entre humanos y no humanos? Estas son algunas de las preguntas que los artículos de este dossier buscan responder.

\section{PROTOTIPAR LO SOCIAL}

Otro aspecto que merece ser tomado en consideración dice relación con las llamadas "políticas ontogicas" Mol, 2005, Law \& Ury, 2004, Maze, 200 dien

Partiendo del supuesto de que los métodos no se limitan a describir una realidad allí afuera", sino que también provoca aquello que dicen describir (Callon, 1999; 2002), es de suma relevancia indagar en los tipos de realidades y configuraciones que producen los procesos de diseño y, especificamente, las dinamicas de prototipado. Tal como lo muestran algunos artículos de este dossier, como el de Lindstrom y Ståhl, el de Fantini y el de Sánchez Criado, las interacciones y saberes que emergen de la práctica del prototipado habilitan particulares experiencias, materializando sucesos $y$ preguntas que van más allá de lo puramente discursivo. Esto implica alejarse de la presunción positivista que pretende una ciencia abocada la production de leyes pollitics, understanding this term not as the possibility of a unified world or of generalised consensus, but on the contrary as a world onen to a polyphony of narratives and voices This process, more than requiring closed solutions invites us to test and prototipe progrescively and delicately events that a llow us to experiment cosmopolitics.

As Isabelle Stengers points out, the cosmopolitical proposal contains the question about how to design a political scenario tha protects us from the anthropocentric egotism according to whic "humlans of good wild decide in the nlame of the generat interest" (2005, p. 1002.). Thus, rethinking a notion of politics not restricted sts is not only a philosophical matter, it is a matter of design.

Cosmopolitics as a matter of design is an invitation to recognise the boundaries and extents of the design methods centred around humans, and to explore forms of de-centralisation through operations of co-designing that allow the inclusion of other, invisibilised entities (Binder et al., 2015; Tironi and Hermansen, 2017. The potentiality of design to investigate the conditions for cosmopolitics is equally a way of taking seriously the role of design in the conservation of the environments for life (Ingold, 2014). What methodological repertoires are necessary to become permeable to the 'more than human' dimensions, tracking the multiple processes and ontologies that characterise our life? What type of embodied and materialised wisdom enables the design processes that challenge the forms of knowledge production of the social sciences to think about cosmopolitics and the cohabitation then-humans? These are some of the questions that the articles in this dossier seek to answer.

\section{PROTOTYPING THE SOCIAL}

Another aspect that deserves to be taken into consideration relates to the so-called 'ontological politics' (Mol, 2005; Law \& Urry, 2004; Mazé, 2016) which the practices of the design process set in motion.

Starting from the assumption that the methods are not confined to describing a reality "out there", but they also provoke that which they affirm to describe (Callon, 1999; 2002) it is of great relevance to inquire into the types of realities and configurations that the design processes produce and, specifically, the dynamics of prototyping. Just as some of the articles in this dossier demonstrate, as those by Lindström and Ståhl, Fantini, and Sánchez Criado, the interactions and knowledges that emerge in the practice of prototyping enable particular experiences, materialising events and questions that go beyond the mere discourse This implies moving away from the positivist assumption that pretends a science devoted to the production of universal laws, and to open the question of the establishment of the social sphere to the participation of multiple agents.
En esta dirección, algunos autores han señalado que las cualidades abiertas de los prototipos los han convertido en un instrumento político para las recientes experiencias de democratización cultural, precipitando nuevas formas construcción de colectivosy ciudadon a Corsin liménez, 2013).

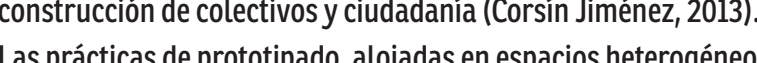
Laspract como medialabs, hacklabs, fablabs, makerspaces, techishops, etc., estarian dluyendo las frontras conn extruid some consionalidady

Disalvo (2014) plantea que una de las singularidades del prototipado tiene que ver con la capacidad de enactar modos de hacer politica a través de actividades socio-materiales concretas. Esto es, precipita dinámicas de critical making, donde se van dilucidando los compromisos e intereses de los actores involucrados, asi como los escenarios y los problemas que nacen a partir de la confección de un determinado artefacto (DiSalvo, 2014). Por otra parte, Mike Michael (2012) ha enfatizado la importancia de considerar la lógica iterativa y malportad (misbehave) del prototipado como una manera de generar situaciones idióticas en el sentido de Stengers (2005), esto es, situaciones menos interesadas en la resolución de problemas que en la exploraciony creación de escenarios posibles. Para Michael (2012), Ll lógica del prototipado ofrece la oportunidad para ralentizar los procesos y generar lo que el autor llama inventive problem making, esto es, el desarrollo de materiales especulativos para re-pensar el significado de los eventos sociales. Se trata de una operación que hace posible materializa narrativas que otros métodos de investigación no logran visualizar, tal como demuestran en este dossier los artículos de Fantini, de Lindström y Ståhl y de Lenskjold y Jönsson

El carácter provisional y frágil del prototipo (su naturaleza consiste en generar conocimiento desde la producción de fallas) surge entonces como una característica fundamental, puesto que de aquí deriva su capacidad para gatillar eventos imprevistos (Michael, 2012). Asimismo, esta maleabilidad y vulnerabilidad del las agenciasy s situaciones en juego (Tironi \& Hermansen, 2017). El prototipado no impone ni pre-configura, sino que su razón de ser es dejar que surjan realidades a partir de sus sucesivos de ser es dejar que surjan realidades a partir de sus sucesivos
fracasos y fall as, obligando a reconsiderar otros caminos $y$ preguntas. Se trata de una actividad emergente que permite la exploración de escenarios posibles (Tironi \& Hermansen, 2017; Binder et al., 2015; Disalvo, 2014), y se yergue como un mecanismo privilegiado para reensamblar y reflexionar sobre lo que podría llegar a ser. El prototipado instaura una comprensión de la política abierta a lo potencial, una relación con el presente basada en lo especulativo: Logra hacer presente, con el presente basada en lo especulativo: logra hacer presente,
performativamente, mundos y posibilidades políticas todavía performativamente, mundosy posibilidades polfiticas todavía
In this direction, some authors have pointed out that the open qualities of prototypes have transformed them into a political instrument for the recent experiences of cultural democratization, precipitating new forms of construction of collectives and citizenship (Corsín Jiménez, 2013). The practices of prototyping, hosted in heterogenous spaces like medialabs, hacklabs, fablabs, makerspaces, techshops, etc., would be diluting the conventional experts and non-experts, conforming an epistemic culture based on collaboration the provisionat, and recycling (Corsín Jiménez, 2013).

Disalvo (2014) suggests that one of the singularities of prototyping has to do with the capacity to enact ways of making politics through concrete socio-material activities. In other

words, $t$ preetipitates dynamics of critical making, where the compromises and interests of the actors involved are elucidated, together with the scenarios and problems that emerge from the construction of a certain artefact (Disalvo, 2014). On the other hand, Mike Michael (2012) has emphasised the importance of considering the iterative and misbehaved logics of prototyping as a way to generate idiotic situations in the sense of Stengers (2005), that is to say, situations less interested in the resolution of problems than in the exploration and creation of possible scenarios. For Michael (2012), the logics of prototyping offers an opportunity of slowing down the processes and generate what the author calls 'inventive problem making', that is, the development of speculative materials to re-think the meaning of social events. It has to do with an operation that enables the materialisation of narratives that other research methodologies cannot fully visualise, as the articles by Fantini, by Lindstrom and Ståhl and by Lenskjöld and Jönsson demonstrate in this dossier.

The provisional and fragile character of the prototype (its nature consists in generating knowledge from the production of failures) emerges then as a fundamental characteristic, since here lays its ability to trigger unexpected events (Michael, 2012). Furthermore, this malleability and vulnerability of the prototype makes possible the unfolding of an 'ethics of care' with the agencies and situations at stake (Tironi \& Hermansen, 2017).

Prototyping does not impose or reconfigure, but its reason to be is to allow realities based on its successive failures and

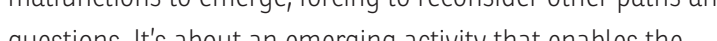
a exstons th's a

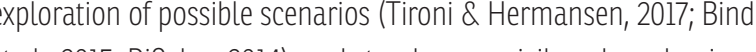
et al, 2015, DSalvo, 201), and stands as a privinged mechanism to

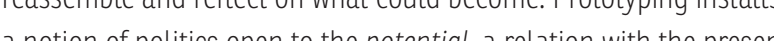
a notion of polttes open to the potential, a relation with the present political worlds and possibilities that are still absent. The work of 
transformar lo político en un campo de experimentación, y en lugar de determinar a priori los intereses y agencias en juego, se abre a las múttiples posibilidades que emergen desde el presente. La actividad del prototipado compone un terreno donde los temas, problemas e intereses políticos van co-emergiendo en los procesos de probar. Si bien todo diseño es una forma de proposición, y en ese sentido, una forma de ficción (Dunne \& Raby, 2013), La radicalidad política del prototipado consiste en proveer las condicionees para la experimentación de lo posible .

Lanzarse en procesos de prototipado es implicarse en formas de conocimiento incompletas e inacabadas, abiertas a lo "que podria llegar a ser" (Iminof, Quiros, a de Toledo, 2016; Mazé, 2016; Sauransky, Wikkie, \& Rosengarten, 2017). La actividad procesual del prototipo esta investida de cierta vitalidad que permite desafiar la condena de tener que pensar que las cosas son como son. Invita a re-pensar el rol de la intervención como herramienta para la generación de nuevos conocimientos y de nuevos modos de involucramiento con los temas.

Podrímos decir que los procesos de prototipado descansan en la siguiente premisa: que las cosas adquieren existencia, grados de realidad, en la medida en que se hacen visibles, tangibles 0 audibles a través del proceso de prueba. En este sentido, la inteligencia de prototipado, entendido este como actividad relacional y abierta a la interacción, nos protege de las formas de pensamiento lineal y totalizador que busca soluciones pre-configuradas antes de comprender los problemas. Estimula la experimentación política y la producción de nuevas formas de entender la vida social. El prototipado no reduce su quehacer a una lógica de problem solving —-muy arraigada en la cultura smart de nuestros tiempos-, sino que también es una forma de problem making, instaurando modos inventivos de explorar y sensibilizarse con los problemas. En suma, el

prototipado transforma el hacer en una forma de investigaion

y experimentación política y al mismo tiempo, conviertela

investigación en una forma de hacer emerger nuevas realidades

\section{SOBRE LOS CONTENIDOS DE ESTE NÚMERO}

Bajo una heterogeneidad de repertorios, casoss y problemáticias, los articulos aquí reunidos establecen cruces y tensiones que desaffian los enunciados convencionales sobre el diseño, incorporando como e je

reflexivo las múttiples manifestaciones socio-politicas de esta práctica.

Eden Medina, desde una perspectiva que podríamos llamar de

"arqueología de las tecnologías", nos sumerge en una aguda reflexión

respecto al rol del diseño en la manufacturación y materialización de

ciertos valores ideológicos que sustentan los proyectos de desarrollode

una nación A través de la compracín de tres sistemas computacion

(OGAS, Cybersyn y ARPANET), la autora revela los complejos

entrelazamientos que existen entre los programas politicos de las naciones

y las decisiones de diseño que prototyping composes a terrain where the political issues, problems and interests start to co-emerge in the process of testing. If all (Dis is a form of proposition, and in this sense, a form of fiction (Dunne \& Raby 2013), the political radicality of prototyning consist in providing the conditions for the experimentation of the possibte, articulating multiple alternatives of the real.

Tom embark in processes of prototyping is to get involved in forms of knowledge that are incomplete and unfinished, open to the 'what could become (Imhorf, Quiros, \& de Toledo, 2016; Maze, 2016, Sauransky, Wilkie, \& Rosengarten, 2017). The procedural activity of prototyping is invested of a certain vitality that allows it to defy the sentence of having to think that things are the way they are. It invites us to re-think the role of intervention as a tool for $t$ generation of new knowledge and new modes of getting involved with the issues.

We could say that the processes of prototyping rest on the following premise: things acquire existence, degrees of reality, in the measure that they become visible, tangible or audible through the process of testing. In this sense, the intelligence of prototyping, understood as a relational activity and open to interaction, protects us from the linear and totalising forms of thought that seek pre-configured solutions before understanding the problems. It stimulates political experimentation and the production of new ways of understanding social life. The business of prototyping is not reduced to a logic of problem solving — deeply rooted in the smart culture of our times-, but is also a sort of problem making, installing inventive modes of exploring and becoming sensitive to the problems. In sum, prototyping transforms the making into a form of political research and experimentation and, at the same time, transforms research into a way of making new realities merge.

ABOUT THE CONTENTS IN THIS ISSUE

Under a hetetrogeneity of repertoires, cases and issues, the articles collected here establish crossings and tensions that challenge the conventional principles of design, incorporating as a reflective axis the multiple soci-

poolitical manifestations of this practice.

Eden Medina, fiom a perspective that we may call 'archaeology of technotogies,' Immerses us in a sharp reflection on the role of design in the manturacturing and materialisation of certain ideological values that support the development projects of nations. Through comparing three computer systems (GGAS, Cybersyn Y ARPANET), the author revealls the and the desian decisions that are deployed. The debate that Medina ofrece interesantes pistas de análisis para la comprensión del rol del diseño en el desarrollo de los sistemas de recolección de datos contemporáneos basado en la retóric del la Smart Cityy el Big Datate einvita a reconsiderer aquellas opciones de diseño que quedan marginadas

Albena Yaneva, por su parte, propone que la "puesta en escena" del los arquitectos - al momento de presentar un determinado proyecto—debe ser concebida como un mecanismo de poder orientado a la elaboración Jersusión dén arquitecto Rem Koolhaas (OMA), Yaneva ofrece una reflexión original respecto de los instrumentosy y repertorios que vehicula la a rquitectura para enactar, material y politicamente, los pubblicos de un determinado proyecto arquitectónico. Su análisis revela los particulares agenciamientos socio-materiales que transforman las presentaciones de los arquitectos en

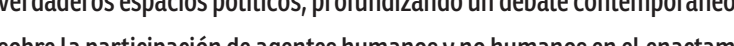
sobre la participación de agentes de la politicay los públicas

Articular y escenificar nuevos escenarios para la politicica desde la arquitectura es precisamente el desanfo que Ignacio Farlias y Gonzalo Correa desarrollan en la experiencia pedagogica en que se basa su artícu Eltrabajo se sitúa en un plano abiertamente especulativo y proyectivo, jecutado en el marco de un taller de arquitectura. La pregunta de fondo es cómo podrían ser los parlamentos del futuro para un mundo común, que incluya la representacióny articulación de diversas voces. Basad os en la premisa latouriana de que los parl lamentos modernos han sido Insuficientes para pensar los colectivos y entidades que fundan nuestros mundos, los autores ensayan posibilidades de parlamentos politicos que hagan posible el "ponerse en presencia" de otras ontologías, diagramano formas de diálogo y de visibilidad de las legitimas diferencias entre entidades a veces irreconciliables.

El artículo de Fernando Dominguez Rubio y Uriel Fogué ofrece un marco analitico de gran claridad para comprender los differentes programas sociomateriales auepuede sintetizar el diseñ enel mu do mas Analizando I manera en que la materialididad del diseño puede constitur un mecanismo politicic, Los autores exponen particulares agendas Arstignín A través de diferentes referencins acasosy debates recogidos de A raves de rences

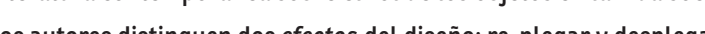
bse Escher destrin a

The Kristina Lindströom y Asa Stàhl proponen un interesante desplazamien analítico y empirico para comprender las dinámicas de co-construcción entre diseñadores y publicos. Stituandose en los debates contemporanneos sobre las formas de co-diseño y colaboración, las autoras plantean que en Lugar de ver a los usuarios como meros validadoreses de futuros productos estos deberían ser considerados en las fases de uso de esos productos desaffiando los modos en que tradicionalmente son concebidos los usuarios en los procesos de diseño. Bajo el supuesto de que los problemas y potencialidades de los objetos y su interacción con los entornos nunca proposes offers interesting clues to analyse for the understanding of the role of design in the development of a system of collection of conter data, based on the retoric of the Smart city and Big Data and invites to reconsider those design options that are left behind.

Albena Yaneva, on her part, proposeses that the 'staging' of architects when they present a certain project - must be conceived as a mechanism power onientied to the elaboration and perstaston of pubtics. Based on an

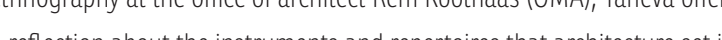
mever to

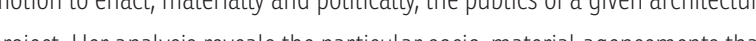

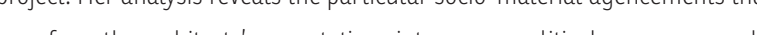

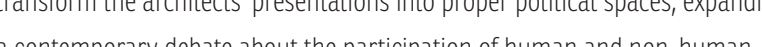
gents in the enactment of politics and publics.

-To articulate and stage new scenarios for politics from within archititcture sprecisely the chatlenge that Ignacio Farias and Gonzalo Correa the teaching experenence on which their article is based. The work is situated in an openly speculative and projective plane, carried out in the context of an architecture studio course. The underlying question is how the parliaments of the future for a common world could be, which include the representation an articulation of different voices. Based on the Latourian premise that modern parliaments have proven insufficient to think the collectives and entities that our worlds found, the authors attempt possibilities of political parliaments that enable the 'standing in presence' of other ontologies, diagramming forms of dialogue and of visibility from the legitimate differences between entities sometimes irreconcilable.

-The article by Fernando Domínguez Rubio and Uriel Fogué offers an analystic framework of great clarity to understand the different sociomateri programs that desion can synthesise in the contemporary world Analying the way in which the materiality of design an constitute ar politicat mechanism, the authors present particular agendas of research around the relation between desion politics and cosmopolitice Through diverse references to cases and debates athered from contemporary literature on the role of obiects in social life, the authors distinguish two effects of desige

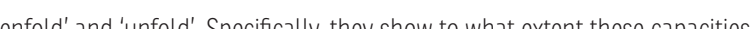

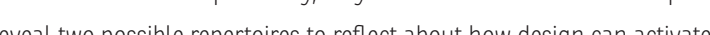

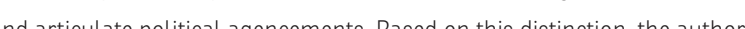
propose three cosmopolitical operations present in design.

Kristina Lindström and Asa Stảhl propose an interesting analytic and empirical shift to understand the dynamics of co-construction between destgners and publics. situating themselves within the contemporary yeobes about forms of co-designing and cottaborating, the euthors pose that Instead of seeing users as mere validators of future products, they should be considered in the phases of usage of those products, challenging the ways ne assumption that the problems and potentialities of objects and the 
pueden ser prefijados, las autoras proponen formas de diseñar-despuésde-diseñar, desafiando los métodos convencionales de entender la colaboración en diseño.

Delfina Fantini, adoptando un enfoque de investigación basado en metodologías del diseño crítico y el diseño especulativo, busca ditucidar los presupuestosy las normatividades que estan detrás de con configur ando nuestras formas de tomar decisiones. Basada en la figur conceptual del idiota, trabajada por Gilles Deleuze I sabelle Stengers, Fantini examina cle los efectos generados a part tir de una intervent inventiva denominada "idloTica", cuyo propositito fue personificar, reftexiva e irónicamente, las lógicasy sesgos de la llamada inteligencia

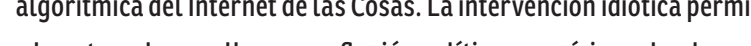
a ta autora desarroltar una reftexion politica y empirica sobre $t o s$ supuestos del funcionamiento a algoritmico, revelando aspectos naturatizados s generando, a mismo tiempo, escenari is posibles sobre otras formas de comprender la inteligencia

La investigación de Tau Ulv Lenskjöldy L Li Jönsson, por su parte, se sitúa en el debate contemporáneo sobre la etnografía multi-especie y rol del diseñoentlageneration defromasde co-existencla que incluy entidades más-que-humanas. Utilizando metodologías del diseño especulativo, los autores analizan los encuentros interespecies (animales y humanos) precipitados por el desarrollo del prototipo experimental Inter Fed. El articulo reflexiona sobre las capacidades de los prototipos para facilitary y proyectar futuras relaciones multiespecies, es deciri, formas de coexistencia que puedan ir más allá de las jerarquías humanas y no-humanas. Los autores muestran las potencialidades del diseño para repensar el mundo común, generando prototipos que permitan extender nuestras formas de entender la ecologí. Desde una perspectiva que articula el activismo politico, las prácticas crialo cilde seras

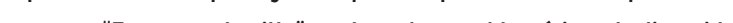
reme The de

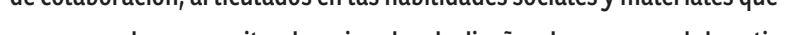

Mas Más allá de la variedad de los temas abordados por estos trabajos, todos ellos manifiestan una curiosidad por re-pensar los modos que tiene el diseño de actuar politicamente. Más que tratar de fijar o convenir formas canónicas de entender la relación entre diseñoy y política, las contribuciones de esta edicion de Diseña subrayan la relevancia empujar las fronteras convencionales del diseño, evidenciando la necesidad de atreverse a imaginar nuevas preguntas.

Finalmente, quiero agradecer todo el apoyo brindado por Ximena Ulibarri, directora de Revista Diseña, y muy especialmente la confianza que depositó en mí para coordinar el trabajo de esta edición interaction with the surroundings can never be prefixed, the authors propose Ways of designing-affer-designing, challenging the conventional ways of

Delfina Fantini, adooting a research anproach based on methodologies from critical design and speculative design, seeks to elucidate the assumptions and the normativity that lay behind algorithmic processing and the man solutions that are configuring our ways of making decisions. Based

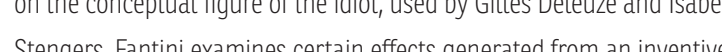
Stengers, Fant exam esceftan efiects generated from an inventive Intervention calted Tlarofic, whose purpose was to personity, retelexvely and Ironicaly, the togics and biases of the so-catted atgorithmic intelligence of the Internet of Things. The tidotici intervention allowed the author to develop a poltical and empirical reflection on the assumptions of algorithmic

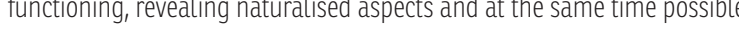
scenarios on other forms of understanding smartness.

The research work of Tau Ulv Lenskjöld and Li Jönsson, on its part, is situated within the contemporary debate on multi-species ethnography and the role of design in the generation of forms of coexsistence that may include more-than-human entities. Using methodologies of speculative design, the authors analyse interspecies encounters (animals and humans precipitated by the development of the experimental prototype Interfed. The article reflects on the capacities of prototypes to facilitate and project future interspecies relations, that is to say, forms of coexistence that may beyond human and non-human hierarchies. The authors demonstrate the potentialities of design to rethink our common world, generating prototypes that allow to extend our ways of understanding ecology.

From a persspective that articulates political activism, the practices of collaborative design and auto-ethnography, Tomás Sánchez Criado's article analyses the formats of work and self-care that challenge the assistentialist models based on the separation between expert and non-expert. From the description of the project En torno a la silla - dedicated to problems of the ideal of 'user centred design' or design based on universal solutions in its place, he identififes open and temporary spaces of collaboration, articulated in the social and material abilities that emerge in the situated and singular process of designing in a collective manner.

Beyond the variety of the subjects covered by these works, all of them manifest a curiosity to re-think the ways that design has to act politically. More than trying to agree on canonical forms of understanding the relation between design and politics, the contributions in this issue of Diseña underline the relevance of pushing the conventional boundaries of design,

Finally, would like to thank the support given by Ximena Ulibarri, editor of Revista Diseña, and very specially the trust she's placed in me for the coordination of the work for this issue.

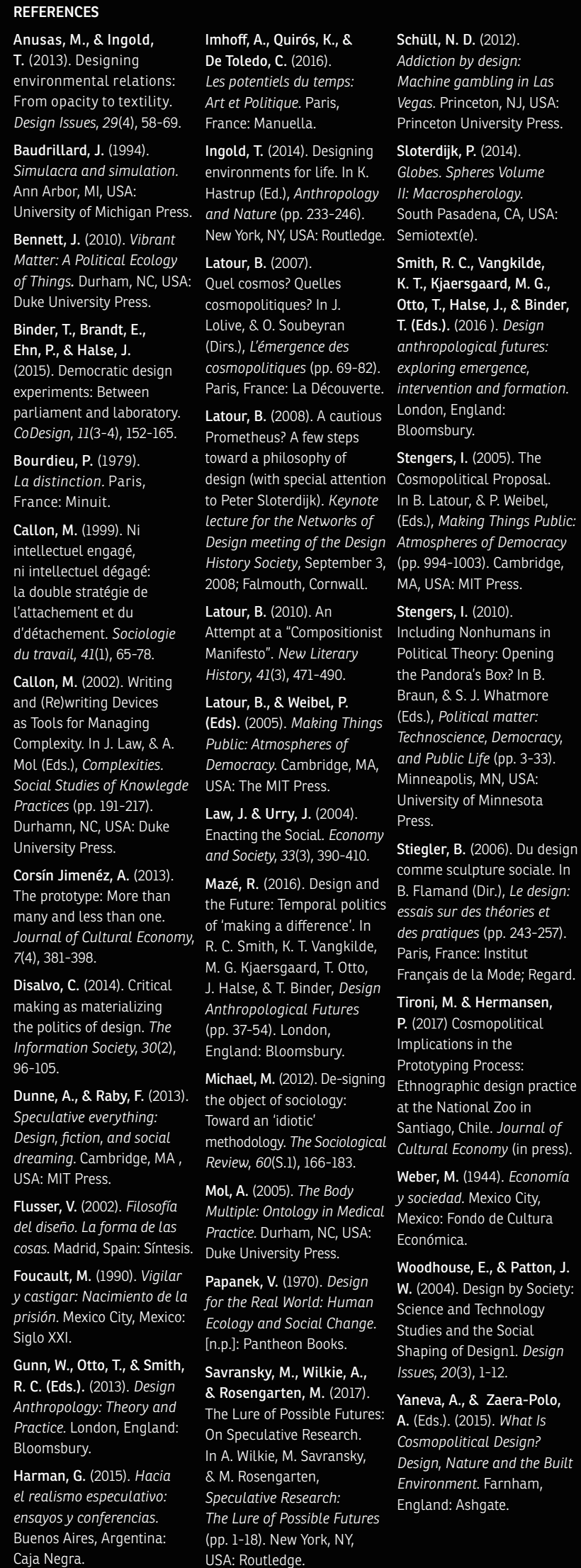

